\title{
HUBUNGAN ANTARA KOMPETENSI PROFESIONALISME DAN MOTIVASI KERJA DENGAN KINERJA GURU DI SMK NEGERI 2 BAUBAU
}

\author{
Kosilah \\ Program Studi Pendidikan Bahasa dan Sastra Indonesia, \\ Fakultas Keguruan dan Ilmu Pendidikan, \\ Universitas Muhammadiyah Buton, Jl. Betoambari No. 36 Baubau. \\ E-mail:kosilah81@gmail.com
}

\begin{abstract}
Abstrak
Tujuan dari penelitian ini adalah untuk mengetahui hubungan yang signifikan antara kompetensi profesionalisme dengan kinerja guru di SMK Negeri 2 Baubau. Penelitian ini menggunakan rancangan penelitian korelasional. Penelitian korelasi berkaitan dengan pengumpulan data untuk menentukan ada atau tidaknya hubungan antara dua variabel atau lebih dan seberapakah tingkat hubungannya. Hasil penelitian ini menunjukan bahwa tingkat kompetensi profesionalisme, motivasi kerja dan kinerja guru di SMK Negeri 2 Baubau berada pada kategori sedang, kompetensi profesionalisme mempunyai hubungan positif dan signifikan dengan kinerja guru di SMK Negeri 2 Baubau yang berarti bahwa semakin tinggi kompetensi profesionalisme maka semakin tinggi pula kinerja guru, motivasi kerja mempunyai hubungan positif dan signifikan dengan kinerja guru di SMK Negeri 2 Baubau yang berarti bahwa semakin tinggi motivasi kerja maka semakin tinggi pula kinerja guru dan kompetensi profesionalisme dan motivasi kerja mempunyai hubungan positif dan signifikan dengan kinerja guru di SMK Negeri 2 Baubau. Apabila kompetensi profesionalisme dan motivasi kerja ditingkatkan maka kinerja guru dapat meningkat.
\end{abstract}

Kata kunci: kompetensi, kinerja, dan profesionalisme.

\begin{abstract}
The purpose of this study was to determine the significant relationship between professionalism competence and teacher performance in SMK Negeri 2 Baubau. This study uses correlational research design. Correlation research is concerned with collecting data to determine whether or not the relationship exists between two or more variables and how relevant is the relationship. The results of this study indicate that the level of professional competence, work motivation and performance of teachers in SMK Negeri 2 Baubau is in the category of moderate, professionalism competence has a positive and significant relationship with the performance of teachers in SMK Negeri 2 Baubau which means that the higher the competence of professionalism then the higher also Performance of teachers, work motivation has a positive and significant relationship with the performance of teachers in SMK Negeri 2 Baubau which means that the higher the motivation of work the higher the performance of teachers and professionalism competence and work motivation has a positive and significant relationship with the performance of teachers in SMK Negeri 2 Baubau. If the competence of professionalism and work motivation is improved then the teacher's performance can increase.
\end{abstract}

Keywords: competence, performance, and professionalism. 


\section{SANG PENCERAH}

Volume 2, Nomor 2, Agustus 2016, ISSN 2460-5697, Hlm. 20-28

Kosilah: Hubungan Antara Kompetensi Profesionalisme

\section{Pendahuluan}

Pendidikan merupakan salah satu faktor yang memegang peranan penting dalam usaha untuk peningkatan mutu sumber daya manusia. Sumber daya manusia yang berkualitas sangat diperlukan untuk memajukan pembangunan suatu negara. Semakin tinggi dan berkualitas sumber daya manusianya, maka semakin baik tingkat pendidikannya, dan demikian pula sebaliknya. Sebuah negara yang maju merupakan sebuah negara yang mempunyai mutu pendidikan yang berkualitas. Adapun mutu pendidikan di Indonesia yang masih rendah menjadi permasalahan tersendiri yang krusial hingga saat ini. Terkait dengan masalah rendahnya mutu pendidikan, salah satu komponen yang berperan penting adalah guru dan kinerjanya. Guru sebagai pemegang peran utama dalam mengarahkan atau mengelola seluruh komponen yang terkait dalam kegiatan belajar harus mempunyai bekal yang memadai sehingga dapat mengorganisir dan mengelola kegiatan belajar mengajar secara optimal. Tanpa adanya kompetensi profesionalisme guru yang memadai maka upaya peningkatan mutu pendidikan sekolah pun juga belum dapat tercapai secara maksimal.

Adanya keragaman kompetensi profesionalisme guru dalam menguasai dan mengorganisir proses pembelajaran serta kurangnya pembinaan yang dilakukan untuk meningkatkan kualitas dan profesionalisme guru dalam melaksanakan kinerjanya menjadi masalah tersendiri yang baik secara langsung maupun tidak langsung sangat mempengaruhi tingkat mutu pendidikan. Oleh karena itu, peningkatan kinerja guru menjadi hal yang harus dilaksanakan agar guru dapat melakukan tugas dan fungsinya dengan baik. Berbagai upaya dan strategi harus dilakukan agar kinerja guru tersebut terus meningkat dan dapat mencapai tujuan pendidikan yang telah direncanakan.
Guru yang produktif memiliki karakteristik sebagai berikut: (1) memiliki kecerdasan pikir dan dapat mempelajari kondisi sekitar dengan cepat, (2) memiliki kompetensi secara profesional, (3) memiliki daya kreatifitas dan inovatif yang tinggi, (4) memahami dan menguasai pekerjaannya, (5) belajar dengan cerdik, menggunakan logika, dan mengorganisir pekerjaan dengan efisien, (6) selalu berusaha melakukan perbaikan,(7) dianggap bernilai oleh pengawasnya, (8) memiliki prestasi yang baik dan (9) selalu berupaya untuk meningkatkan kemampuan diri. Menurut Depdiknas (2004) menyatakan bahwa seorang guru harus memiliki standar kompetensi, yaitu (1) komponen kompetensi pengelolaan pembelajaran dan wawasan kependidikan; (2) komponen kompetensi akademik yang sesuai dengan materi pembelajaran; dan (3) pengembangan profesi. Komponen-komponen standar kompetensi guru ini mewadahi kompetensi profesional, personal dan sosial yang harus dimiliki oleh seorang guru.

Selain itu, Depdikbud (1985) juga mengemukakan bahwa guru yang memiliki kinerja yang tinggi merupakan guru yang memiliki kemampuan dasar profesional yang tinggi, yaitu (1) kemampuan menguasai bahan pelajaran yang disajikan; (2) kemampuan mengelola program belajar mengajar; (3) kemampuan mengelola kelas; (4) kemampuan menggunakan media atau sumber belajar; (5) kemampuan menguasai landasan-landasan kependidikan; kemampuan mengelola interaksi belajar mengajar; (7) kemampuan menilai prestasi belajar siswa; (8) kemampuan mengenal fungsi dan program layanan bimbingan dan penyuluhan; (9) kemampuan mengenal dan menyelenggarakan administrasi sekolah; dan (10) kemampuan memahami prinsipprinsip dan menafsirkan hasil-hasil penelitian pendidikan guna keperluan pengajaran. Sepuluh kompetensi itu dapat menumbuhkan guru yang profesional yaitu guru yang ahli dalam bidangnya, memiliki 


\section{SANG PENCERAH}

Volume 2, Nomor 2, Agustus 2016, ISSN 2460-5697, Hlm. 20-28

\section{Kosilah: Hubungan Antara Kompetensi Profesionalisme}

rasa tanggung jawab yang tinggi dan rasa kesejawatan (Sahertian, 1994).

Motivasi kerja juga mempengaruhi kinerja guru pada keseharian dalam melakukan proses pembelajaran. Motivasi kerja yang tinggi menyebabkan seseorang melakukan pekerjaannya dengan lebih baik karena pekerjaanya dilakukan dengan sepenuh hati dan dorongan yang kuat untuk melaksanakannya (Gorton, 1976). Seseorang yang termotivasi, akan mampu melaksanakan segala tugas dan tanggung jawabnya dengan baik, tanpa harus diawasi oleh atasannya. Dengan kata lain bahwa seorang guru yang bekerja dengan maksimal, berarti ia memiliki kinerja yang tinggi. Dengan demikian unjuk kerja yang diperlihatkan seorang guru dalam proses pembelajaran dapat menggambarkan tingkat motivasi guru tersebut. Semakin baik unjuk kerja seorang guru, maka semakin tinggi tingkat motivasi kerjanya. Berdasarkan uraian di atas, maka perlu dilakukan penelitian untuk mengetahui ada tidaknya hubungan antara kompetensi profesionalisme dan motivasi kerja dengan kinerja guru. Berdasarkan uraian di atas, fokus penelitian ini adalah bagaimana hubungan yang signifikan antara kompetensi profesionalisme guru dengan kinerja guru di SMK Negeri 2 Baubau?

Tujuan dari penelitian ini adalah untuk mengetahui hubungan yang signifikan antara kompetensi profesionalisme dengan kinerja guru di SMK Negeri 2 Baubau.

\section{Metode Penelitian}

Penelitian ini menggunakan rancangan penelitian korelasional. Penelitian korelasi berkaitan dengan pengumpulan data untuk menentukan ada atau tidaknya hubungan antara dua variabel atau lebih dan seberapakah tingkat hubungannya (tingkat hubungan dinyatakan sebagai koefisien korelasi) (Sumanto, 1995:97). Dalam penelitian ini, menghubungan antara tiga variabel, yakni mengenai kompetensi profesionalisme dan motivasi kerja terhadap kinerja guru di SMK Negeri 2 Baubau. Adapun dalam penelitian ini, variabel terikatnya adalah kinerja guru, sedangkan variabel bebasnya ada dua, yakni kompetensi profesionalisme dan motivasi kerja guru. Agar variabel-variabel tersebut jelas hubungannya antara satu dengan yang lain, maka perlu disain gambar seperti berikut:

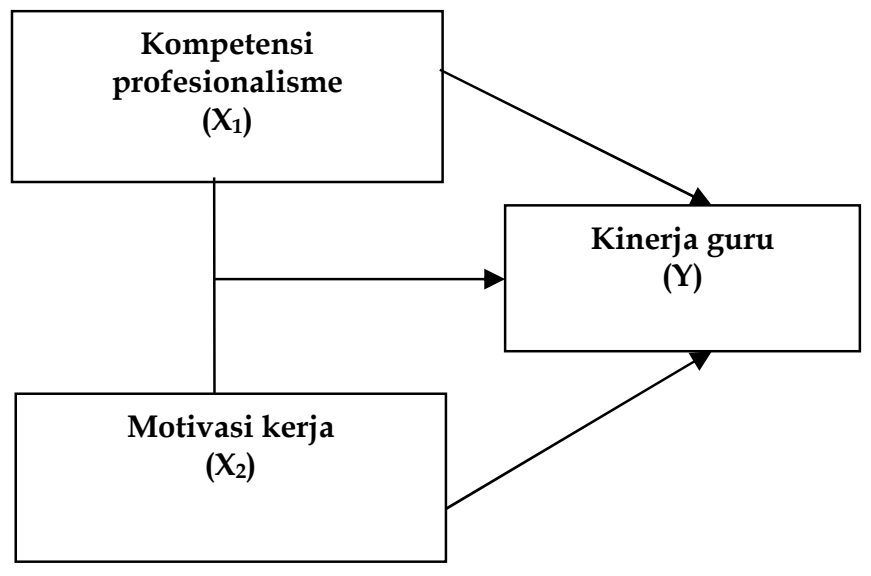

\section{Gambar 1 Rancangan Korelasional Variabel Penelitian}

Secara rinci rancangan tersebut dapat dijelaskan sebagai berikut:

1. Variabel $X_{1}$ dengan variabel $Y$ Hubungan antara kompetensi profesionalisme dengan kinerja guru

2. Variabel $X_{2}$ dengan variabel $Y$ Hubungan antara motivasi kerja dengan kinerja guru

3. Variabel $X_{1}$ dengan variabel $X_{2}$ dengan $Y$ Secara bersama-sama hubungan antara kompetensi profesionalisme dan motivasi kerja dengan kinerja guru

Agar diperolah data-data yang meyakinkan, maka metode penentuan subyek yang akan diteliti harus disesuaikan dengan permasalahan dan tujuan penelitian. Menurut Hadi (2004:169) menyatakan bahwa populasi atau universum adalah seluruh individu yang dimaksudkan untuk diselidiki. Adapun menurut Wardoyo 


\section{SANG PENCERAH}

Volume 2, Nomor 2, Agustus 2016, ISSN 2460-5697, Hlm. 20-28

\section{Kosilah: Hubungan Antara Kompetensi Profesionalisme}

(1982:14) menyebutkan bahwa "populasi adalah semua individu yang diperoleh dari sample dan digeneralisasikan dan dengan demikian sample adalah sebagian individu yang diteliti". Sesuai dengan judul penelitian ini, maka sebagai populasinya adalah seluruh guru yang berstatus PNS maupun bukan PNS di SMK Negeri 2 Baubau tahun pelajaran 2015/2016 yang berjumlah 97 orang.

Sampel penelitian ini adalah seluruh anggota populasi. Dengan demikian dapat dikatakan bahwa penelitian ini menggunakan sampel total. Dan teknik pengumpulan datanya diperlukan data mengenai kompetensi profesionalisme, motivasi kerja dan kinerja guru. Data ini akan diperoleh dengan menggunakan teknik pengumpulan data angket, yakni cara pengumpulan data yang berbentuk pengajuan pertanyaan tertulis melalui sebuah daftar pertanyaan yang sudah dipersiapkan sebelumnya. Sebagai tindak lanjut dari pengumpulan data ialah teknik analisis data. Pada penelitian ini, peneliti akan menggunakan teknik analisis statistik, sehingga data yang diperoleh perlu diwujudkan ke dalam bentuk kuantitatif atau berwujud angka.

Teknik pengolahan datanya menggunakan analisis regresi. Hal ini dikarenakan dalam penelitian ini bertujuan untuk mengetahui hubungan antara dua variabel bebas yakni kompetensi profesionalisme dan motivasi kerja guru dan satu variabel terikat, yakni kinerja guru. Hal tersebut sesuai dengan pendapat Somantri yang menyatakan bahwa "analisis regresi digunakan untuk menelaah hubungan antar dua variabel atau lebih, terutama untuk menelusuri pola hubungan yang modelnya belum diketahui dengan sempurna, atau untuk mengetahui bagaimnan variasi dari beberapa variabel independen mempengaruhi variabel dependen dalam suatu fenomena yang lebih kompleks" (Somantri, 2006:243). Lebih tepatnya, analisis yang digunakan adalah analisis regresi ganda. Hal ini sesuai dengan pendapat Somantri (2006:250) yang menyatakan bahwa analisis regresi ganda adalah alat untuk meramalkan nilai pengaruh atau hubungan dua variabel bebas atau lebih terhadap satu variabel terikat.

\section{Pembahasan}

Kompetensi guru merupakan seperangkat kompetensi yang dimiliki guru. Kompetensi tersebut akan terwujud dalam bentuk penguasaan pengetahuan, keterampilan maupun sikap profesional dalam menjalankan fungsi sebagai guru. Selain itu guru juga harus mampu mendemonstrasikan pengetahuan yang diperoleh serta memiliki sikap dan keterampilan yang dapat diterapkan dalam melaksanakan tugas mengajar sesuai dengan bidangnya dalam mencapai kinerja yang baik. Jika guru tidak memiliki kompetensi maka dapat dikatakan guru tersebut gagal dalam melaksanakan kinerjanya. Untuk itu kompetensi harus dimiliki oleh seorang guru sebagai kemampuan, kecakapan atau keterampilan dan mengembangkan kegiatan pendidikan.

Johnson (1974) yang dikutip oleh Wina Sanjaya, menyatakan" Competency as rational performance which satisfactorily meets the objective for a desired condition " (Wina sanjaya, 2005:145). Dari penjelasan ini, dapat diartikan bahwa kompetensi merupakan perilaku rasional guna mencapai tujuan yang dipersyaratkan sesuai dengan kondisi yang diharapkan. Dengan demikian, suatu kompetensi ditunjukkan oleh penampilan atau unjuk kerja yang dapat dipertanggungjawabkan (rasional) dalam upaya mencapai suatu tujuan. Dari uraian tersebut di atas, dapat ditarik simpulan bahwa kompetensi adalah pengetahuan, keterampilan, dan nilai-nilai dasar yang direfleksikan dalam kebiasaan berpikir dan bertindak seseorang dalam pekerjaannya, 


\section{SANG PENCERAH}

Volume 2, Nomor 2, Agustus 2016, ISSN 2460-5697, Hlm. 20-28

\section{Kosilah: Hubungan Antara Kompetensi Profesionalisme}

sesuai dengan standar kinerja yang dibutuhkan dalam upaya mencapai suatu tujuan.

Menurut Mc. Donald (dalam Sardiman, 1986:73) motivasi adalah perubahan energi dalam diri seseorang yang ditandai dengan munculnya "feeling" dan didahului dengan tanggapan terhadap adanya tujuan. Motivasi dikatakan serangkaian usaha untuk menyediakan kondisi-kondisi tertentu, sehingga seseorang itu mau dan ingin melakukan sesuatu. Dengan demikian dapat disimpulkan bahwa motivasi diartikan sebagai serangkaian usaha yang muncul dari dalam diri seseorang, sehingga seseorang memiliki semangat untuk melakukan pekerjaan sesuai dengan harapan. Motivasi berfungsi untuk mendorong manusia dalam bekerja, mengarahkan kerjanya, dan menyelesaikan pekerjaannya untuk mencapai tujuan yang diinginkan (Purwanto, 1987). Penelitian yang telah dilakukan oleh Vroom dan dikembangkan oleh Atkinson (dalam Scoot, 1967) menunjukkan bahwa motivasi kerja itu memiliki hubungan dengan kinerja seseorang. Seseorang yang memiliki motivasi yang tinggi, dapat melaksanakan pekerjaannya dengan maksirnal.

Kinerja diartikan dengan prestasi kerja, pencapaian kerja, hasil kerja, unjuk kerja, dan penampilan kerja (Sedarmayanti, 2000). Mitchell (1987) mengemukakan bahwa kinerja merupakan perpaduan antara kemampuan dan motivasi. Dari pernyataan tersebut, dapat diambil suatu pengertian bahwa untuk mendapat gambaran tentang kinerja seseorang diperlukan kajian khusus tentang kemampuan dan motivasi. Pernyataan tersebut menunjukkan bahwa motivasi kerja memiliki hubungan yang besar dalam meningkatkan kinerja guru. Dengan demikian hal penting yang harus dilakukan untuk meningkatkan kinerja guru adalah meningkatkan motivasi kerja guru. Semakin tinggi motivasi kerja guru, maka akan semakin tinggi pula kinerja guru.
Adapun hasil penelitian dimaksudkan untuk memberikan gambaran umum mengenai penyebaran data dengan menggunakan metode statistik deskriptif, yakni harga rata-rata, standar deviasi, modus, median, dan distribusi frekuensi. Berdasarkan banyaknya variabel dalam penelitian ini maka deskripsi data dikelompokkan menjadi tiga bagian, yaitu : (1) kompetensi profesionalisme, (2) motivasi kerja, dan (3) kinerja guru. Hasil perhitungan statistik deskriptif dan konversi data menjadi skala lima menggunakan tabel berikut.

Tabel 1 Konversi Data ke Skala Lima

\begin{tabular}{cc}
\hline Interval Skor & Kategori \\
\hline Skor $<\mathrm{M}-1,5 \mathrm{SD}$ & Sangat rendah \\
$\mathrm{M}-1,5 \mathrm{SD} \leq \mathrm{skor}<\mathrm{M}-0,5 \mathrm{SD}$ & Rendah \\
$\mathrm{M}-0,5 \mathrm{SD} \leq$ skor $<\mathrm{M}+0,5 \mathrm{SD}$ & Sedang \\
$\mathrm{M}+0,5 \mathrm{SD} \leq \mathrm{skor}<\mathrm{M}+1,5 \mathrm{SD}$ & Tinggi \\
Skor $\geq \mathrm{M}+1,5 \mathrm{SD}$ & Sangat tinggi \\
\hline
\end{tabular}

Keterangan.

M : Mean (rerata) data sampel

SD : Standar deviasi data sampel

Hasil analisis statistik deskriptif menunjukkan bahwa skor variabel 40 sampai 106, harga rerata sebesar 90.36, standar deviasi sebesar 15.53, median sebesar 95.00 dan modus sebesar 97.00. Data kompetensi profesionalisme guru menyatakan, bahwa (1) terdapat 9 atau 9.28\% berada pada kategori sangat rendah; (2) 6 atau 6.19\% pada kategori rendah, (3) 56 atau $57.73 \%$ berada pada kategori sedang; dan (4) 26 atau $26.80 \%$ berada pada kategori tinggi dan tidak ada responden yang berada pada kategori sangat tinggi. Oleh karena itu dapat dikatakan bahwa kompetensi profesionalisme guru di SMK Negeri 2 Baubau pada kategori sedang.

Hasil analisis statistik deskriptif menunjukkan bahwa skor variabel 40 sampai 104, harga rerata sebesar 91.29, standar deviasi sebesar 15.79, median sebesar 96.00 dan modus sebesar 100.00. Sedangkan untuk distribusi frekuensi 


\section{SANG PENCERAH}

Volume 2, Nomor 2, Agustus 2016, ISSN 2460-5697, Hlm. 20-28

\section{Kosilah: Hubungan Antara Kompetensi Profesionalisme}

motivasi kerja guru SMK Negeri 2 Baubau, bahwa (1) terdapat 9 atau $9.28 \%$ berada pada kategori sangat rendah; (2) 59 atau $60.82 \%$ berada pada kategori sedang; dan (3) 29 atau 29.90\% berada pada kategori tinggi dan tidak ada responden yang berada pada kategori sangat tinggi dan rendah. Oleh karena itu dapat dikatakan bahwa motivasi kerja guru di SMK Negeri 2 Baubau pada kategori sedang.

Hasil analisis statistik deskriptif menunjukkan bahwa skor variabel 22 sampai 71, harga rerata sebesar 58.69, standar deviasi sebesar 8.79, median sebesar 60.00 dan modus sebesar 60.00. Sedangkan untuk distribusi frekuensi kinerja guru SMK Negeri 2 Baubau, bahwa (1) terdapat 6 atau $6.19 \%$ berada pada kategori sangat rendah; (2) 4 atau $4.12 \%$ berada pada kategori rendah; (3) 64 atau $65.98 \%$ berada pada kategori sedang; dan (4) 23 atau $23.71 \%$ bertada pada kategori tinggi dan tidak ada responden yang berada pada kategori sangat tinggi. Oleh karena itu dapat dikatakan bahwa kinerja guru di SMK Negeri 2 Baubau pada kategori sedang.

Hasil analisis regresi sederhana menunjukkan bahwa semakin tinggi tingkat kompetensi profesionalisme maka semakin tinggi pula kinerja guru. Temuan dalam penelitian ini sekaligus menolak $\mathrm{H}_{0}$ dan menerima $\mathrm{H}_{1}$ yang menyatakan "ada hubungan yang signifikan antara kompetensi profesionalisme dengan kinerja guru SMK Negeri 2 Baubau". Daya ramal persamaan regresi hubungan antara kompetensi profesionalisme $\left(X_{1}\right)$ terhadap kinerja guru $(\mathrm{Y})$ dapat diketahui dari hasil koefisien determinasinya. Dari hasil analisis diperoleh koefisien determinasi sebesar 0.464 yang berarti bahwa $46.4 \%$ variasi variabel kinerja guru dapat dijelaskan oleh variabel kompetensi profesionalisme. Sedangkan 53.6\% lainnya ditentukan oleh variabel lain yang tidak diteliti dalam penelitian ini. Besarnya kontribusi kompetensi profesionalisme terhadap kinerja guru dapat dilihat dari nilai adjusted $R$ Square yaitu 0.458 . Nilai ini memberikan pengertian bahwa kontribusi kompetensi profesionalisme terhadap kinerja guru sebesar $45.80 \%$.

Berdasarkan dari bantuan program SPSS versi 17.00, diperoleh $F_{\text {hitung }}$ sebesar 95.142 dengan tingkat signifikansi 0.00 kurang dari 0.05. Dengan demikian model persamaan regresi yang diperoleh dapat dinyatakan signifikan. Oleh karena itu persamaan regresi $\mathrm{Y}^{\prime}=22.739+0.394 \mathrm{X}_{2}$ dapat digunakan untuk menjelaskan dan mengambil kesimpulan lebih lanjut mengenai hubungan antara motivasi kerja dengan kinerja guru. Dari persamaan regresi $Y^{\prime}=22.739+0.394 X_{2}$ mempunyai arti : (1) apabila motivasi kerja $\left(\mathrm{X}_{2}\right)=0$ maka kinerja guru (Y) dapat ditaksir sebesar 22.739, dan (2) apabila terjadi perubahan motivasi kerja $\left(X_{2}\right)$ sebesar satu satuan maka kinerja guru dapat ditaksir sebesar 0.394 pada satuan konstanta 22.739.

Perhitungan korelasi sederhana terhadap pasangan data variabel motivasi kerja $\left(X_{2}\right)$ dengan kinerja guru $(Y)$ menghasilkan harga koefisien korelasi $\mathrm{r}$ 0.707. Nilai tersebut menjelaskan bahwa terdapat hubungan yang positif antara motivasi kerja dengan kinerja guru. Untuk mengetahui apakah koefisien korelasi r yang diperoleh signifikan atau tidak, dilakukan pengujian dengan menggunakan analisis ujit. Hasil analisis uji-t diperoleh nilai $t$ hitung sebesar 9.574 dengan tingkat signifikansi 0,000 kurang dari $\alpha=0.05$. Hal ini menunjukkan bahwa koefisien korelasi antara motivasi kerja $\left(X_{2}\right)$ dengan kinerja guru (Y) signifikan.

Hasil analisis regresi sederhana tersebut menunjukkan bahwa semakin tinggi tingkat motivasi kerja maka semakin tinggi pula kinerja guru. Temuan dalam penelitian ini sekaligus menolak $\mathrm{H}_{0}$ dan menerima $\mathrm{H}_{1}$ yang menyatakan "ada hubungan yang signifikan antara motivasi kerja dengan kinerja guru SMK Negeri 2 


\section{SANG PENCERAH}

Volume 2, Nomor 2, Agustus 2016, ISSN 2460-5697, Hlm. 20-28

Kosilah: Hubungan Antara Kompetensi Profesionalisme

Baubau". Daya ramal persamaan regresi hubungan antara motivasi kerja $\left(\mathrm{X}_{2}\right)$ terhadap kinerja guru $(\mathrm{Y})$ dapat diketahui dari hasil koefisien determinasinya. Dari hasil analisis diperoleh koefisien determinasi sebesar 0.500 yang berarti bahwa $50.0 \%$ variasi variabel kinerja guru dapat dijelaskan oleh variabel motivasi kerja. Sedangkan $50.0 \%$ lainnya ditentukan oleh variabel lain yang tidak diteliti dalam penelitian ini.

Besarnya kontribusi motivasi kerja terhadap kinerja guru dapat dilihat dari nilai adjusted $R$ Square yaitu 0.495. Nilai ini memberikan pengertian bahwa kontribusi motivasi kerja terhadap kinerja guru sebesar $49.50 \%$. Berdasarkan hasil analisis regresi linear berganda, hubungan antara kompetensi profesionalisme $\left(X_{1}\right)$ dan motivasi kerja $\left(\mathrm{X}_{2}\right)$ dengan kinerja guru $(\mathrm{Y})$ diperoleh nilai koefisien regresi $b_{1}=0.168$, $\mathrm{b}_{2}=0.255$ dan nilai konstanta $\mathrm{a}=20.200$. Dengan demikian diperoleh persamaan regresi berganda yaitu $\mathrm{Y}^{\prime}=20.200+0.168 \mathrm{X}_{1}$ $+0.255 \mathrm{X}_{2}$. Untuk mengetahui apakah model persamaan regresi tersebut dapat digunakan untuk menarik kesimpulan ataua apakah persamaan regresi yang telah diperoleh signifikan atau tidak, dapat diketahui dengan menggunakan analisis variansi (ujiF). kriteria penilaian adalah jika nilai signifikansi (probabilitas) kurang dari 0,05 maka persamaan regresi adalah signifikan, demikian pula sebaliknya.

Dari persamaan regresi $\mathrm{Y}^{\prime}=20.200+$ $0.168 \mathrm{X}_{1}+0.255 \mathrm{X}_{2}$ mempunyai arti : (1) apabila kompetensi profesionalisme $\left(X_{1}\right)=0$ dan motivasi kerja $\left(X_{2}\right)=0$ maka kinerja guru (Y) dapat ditaksir sebesar 20.200, (2) apabila terjadi perubahan kompetensi profesionalisme $\left(\mathrm{X}_{1}\right)$ dan motivasi kerja $\left(\mathrm{X}_{2}\right)$ sebesar satu satuan maka kinerja guru dapat ditaksir sebesar 0.168 dan 0.255 pada satuan konstanta 20.200. Perhitungan korelasi ganda terhadap pasangan data variabel kompetensi profesionalisme $\left(\mathrm{X}_{1}\right)$ dan motivasi kerja $\left(\mathrm{X}_{2}\right)$ dengan kinerja guru $(\mathrm{Y})$ menghasilkan harga koefisien korelasi $r$
0.726. Nilai tersebut menjelaskan bahwa terdapat hubungan yang positif antara kompetensi profesionalisme dan motivasi kerja dengan kinerja guru. Hasil analisis regresi ganda sebagaimana tersebut dapat disimpulkan bahwa semakin tinggi tingkat kompetensi profesionalisme dan motivasi kerja maka semakin tinggi pula kinerja guru. Temuan dalam penelitian ini sekaligus menolak $\mathrm{H}_{0}$ dan menerima $\mathrm{H}_{1}$ yang menyatakan "ada hubungan yang signifikan antara kompetensi profesionalsme dan motivasi kerja dengan kinerja guru SMK Negeri 2 Baubau".

Daya ramal persamaan regresi hubungan antara kompetensi profesionalisme $\left(X_{1}\right)$ dan motivasi kerja $\left(X_{2}\right)$ terhadap kinerja guru $(\mathrm{Y})$ dapat diketahui dari hasil koefisien determinasinya. Dari hasil analisis diperoleh koefisien determinasi sebesar 0.527 yang berarti bahwa 52.7\% variasi variabel kinerja guru dapat dijelaskan oleh variabel kompetensi profesionalisme dan motivasi kerja. Sedangkan 47.3\% lainnya ditentukan oleh variabel lain yang tidak diteliti dalam penelitian ini. Besarnya kontribusi kompetensi profesionalisme dan motivasi kerja terhadap kinerja guru dapat dilihat dari nilai adjusted $R$ Square yaitu 0.517. Nilai ini memberikan pengertian bahwa kontribusi kompetensi profesionalisme dan motivasi kerja terhadap kinerja guru sebesar $51.70 \%$.

Hasil analisis statistik deskiptif untuk variabel tingkat kompetensi profesionalisme di SMK Negeri 2 Baubau sebagian besar memiliki berkategori sedang. Berdasarkan pengujian hipotesisi diperoleh nilai korelasi antara kompetensi profesionalisme dengan kinerja guru sebesar 0.464 dengan nilai signifikan 0,000 kurang dari 0.05. Dengan demikian hipotesis $\mathrm{H}_{0}$ ditolak dan $\mathrm{H}_{1}$ diterima yang berarti "ada hubungan yang signifikan antara kompetensi profesionalisme dengan kinerja guru". Hasil penelitian ini didukung oleh Gordon dan Burch (1997:381) guru yang profesional atau 


\section{Kosilah: Hubungan Antara Kompetensi Profesionalisme}

guru yang mempunyai kinerja yang tinggi adalah guru yang efektif dalam menjalin hubungan dengan peserta didik sehingga terjadi saling pengertian, saling percaya antara kedua belah pihak. Kompetensi profesional guru merupakan kemampuan dasar seorang guru dalam melaksanakan tugas keguruannya dengan kemampuan tinggi, baik sebagai pengajar, pembimbing maupun administrator yang dilaksanakan secara bertanggung jawab dan layak.

Hasil analisis statistik deskiptif untuk variabel motivasi kerja guru di SMK Negeri 2 Baubau sebagian besar berkategori sedang. Berdasarkan pengujian hipotesis diperoleh nilai korelasi antara motivasi kerja dengan kinerja guru sebesar 0.707 dengan nilai signifikan 0,000 kurang dari 0.05. Dengan demikian hipotesis $\mathrm{H}_{0}$ ditolak dan $\mathrm{H}_{1}$ diterima yang berarti "ada hubungan yang signifikan antara motivasi kerja dengan kinerja guru". Hal ini berarti bahwa pada umumnya kinerja yang tinggi dihubungkan dengan motivasi yang tinggi. Sebaliknya, motivasi yang rendah dihubungkan dengan kinerja yang rendah. Kinerja seseorang kadang-kadang tidak berhubungan dengan kompetensi yang dimiliki, karena terdapat faktor diri dan lingkungan kerja yang mempengaruhi kinerja. Kinerja yang tinggi adalah fungsi dan interaksi antara motivasi, kompetensi dan peluang sumber daya pendukung.

Berdasarkan nilai korelasi berganda natara kompetensi profesionalisme dan motivasi kerja dengan kinerja guru di SMK Negeri 2 Baubau sebesar 0.527 dengan nilai signifikan 0,000 kurang dari 0.05. Dengan demikian hipotesis $\mathrm{H}_{0}$ ditolak dan $\mathrm{H}_{1}$ diterima yang berarti "ada hubungan yang signifikan antara kompetensi profesionalisme dan motivasui kerja dengan kinerja guru secara bersama-sama".

\section{Simpulan}

Simpulan penelitian ini bahwa tingkat kompetensi profesionalisme, motivasi kerja dan kinerja guru di SMK Negeri 2 Baubau berada pada kategori sedang, kompetensi profesionalisme mempunyai hubungan positif dan signifikan dengan kinerja guru di SMK Negeri 2 Baubau yang berarti bahwa semakin tinggi kompetensi profesionalisme maka semakin tinggi pula kinerja guru, motivasi kerja mempunyai hubungan positif dan signifikan dengan kinerja guru di SMK Negeri 2 Baubau yang berarti bahwa semakin tinggi motivasi kerja maka semakin tinggi pula kinerja guru dan kompetensi profesionalisme dan motivasi kerja mempunyai hubungan positif dan signifikan dengan kinerja guru di SMK Negeri 2 Baubau. Apabila kompetensi profesionalisme dan motivasi kerja ditingkatkan maka kinerja guru dapat meningkat.

\section{Daftar Pustaka}

Depdikbud. 1985. Bahan Penataran dan Bahan Referensi Penataran. Dirjen DIKTI. Jakarta.

Depdiknas. 2004. Standar Kompetensi Guru Sekolah Menengah Atas. Jakarta: Dirjen Dikdasmen.

Gorton, R.A. 1976. Schooldministration; Challenge and Opportunity for Leadership. Dubuque Lowa: MWC Brown Company Publisher.

Mitchell, T.R. 1987. People in Organization Understanding the Behavior. Kogakhusa: McGraw-Hill Book Company.

Purwanto. 1987. Psikologi Pendidikan. Bandung: PT Remaja Rosdakarya. 


\section{SANG PENCERAH}

Volume 2, Nomor 2, Agustus 2016, ISSN 2460-5697, Hlm. 20-28

\section{Kosilah: Hubungan Antara Kompetensi Profesionalisme}

Sahertian, P.A. 1994. Profil Pendidik Profesional. Yogyakarta: Andi Offset.

Sardiman, A.M. 1986. Interaksi dan Motivasi Belajar Mengajar. Jakarta: CV. Rajawali.

Scoot, W.G. 1967. Human Relation in Management: a Behavioral Science Approach. Homewood: illonis, Richard D. Irwin,lnc.

Sedarmayanti. 2000. Sumber Daya Manusia dan Produktifitas Kerja. Bandung: Mandar Maju.

Somantri, A. 2006. Aplikasi Statistik dalam Penelitian. Bandung: Pustaka Setia.

Sriwiyana, Hadi. 2004. Metodogi Penelitian: Kumpulan Materi Kuliah II. Malang: Universitas Kanjuruhan.

Timpe, A.D. 1989. The Art and Science of Bussiness Management Performance. New York: Kend Publishing.

Wina, Sanjaya. 2005. Pembelajaran dalam Implementasi Kurikulum Berbasis Kompetensi. Jakarta: Prenada Media. 